\title{
Testers in supersweet corn lines
}

\author{
Thiago Hideyo Nihei $^{1}$ Filipe Augusto Bengosi Bertagna ${ }^{2 *}$ (D) Maurício Carlos Kuki ${ }^{2}$ \\ Carlos Alberto Scapim $^{3}$ Ronald José Barth Pinto ${ }^{3}$ Antônio Teixeira do Amaral Júnior ${ }^{4}$
}

${ }^{1}$ Programa de Pós-graduação em Agronomia (PGA), Universidade Estadual de Maringá (UEM), Maringá, PR, Brasil. 2Programa de Pós-graduação em Genética e Melhoramento (PGM), Universidade Estadual de Maringá (UEM), 87020-900, Maringá, PR, Brasil. E-mail: filipeabbertagna@outlook.com. *Corresponding author.

${ }^{3}$ Departamento de Agronomia, Universidade Estadual de Maringá (UEM), Maringá, PR, Brasil.

${ }^{4}$ Departamento de Agronomia, Universidade Estadual Norte Fluminense Darcy Ribeiro (UENF), Campos dos Goytacazes, RJ, Brasil.

ABSTRACT: The purpose of this study was to evaluate the discriminatory capacity of tester lines for tropical corn lines converted to supersweet shrunken (sh2) gene, for the development of hybrids adapted to tropical conditions. Lines were used as female parents in crosses with three testers: open-pollinated mixed variety; supersweet line L4; supersweet commercial hybrid Tropical Plus. Four trials were carried out to evaluate topcrosses in Maringá - PR e Sabáudia - PR, Brazil in the main growing season of 2015/16. The following traits were evaluated: total ear weight (TEW, in $\mathrm{kg}$ ), commercial ear weight (CEW, in $\mathrm{kg}$ ) and total soluble solids (TSS, in $\left.{ }^{\circ} \mathrm{Brix}\right)$. The GCA estimates for TEW and CEW were highest for L4. The lines Balu-114 and UEM-25 were selected based on the effects of $\hat{g}_{1}$ for the traits studied and should be used in the establishment of base populations for the breeding of superior lines. The $\hat{S}_{i j}$ value for TEW was highest for cross BALU-182x Tropical, while for CEW was the highest value for cross BALU-94 x Mista.

Key words: diallel analysis, general and specific combining ability topcross, sweet corn, tester.

Avaliação de testadores em linhagens de milho superdoce

RESUMO: O presente trabalho teve como objetivo avaliar o desempenho de testadores quanto à capacidade de discriminação de linhagens tropicais convertidas à superdoce, por meio da incorporação do gene shrunken (sh2), visando a produção de híbridos adaptados às condições tropicais. As linhagens utilizadas como parentais femininos foram os testadores: variedade de polinização aberta Mista; linhagem superdoce L4; híbrido comercial superdoce Tropical Plus. Os quatro experimentos foram conduzidos em Maringá - PR e Sabáudia - PR, na safra verão de 2015/16. As características avaliadas foram: Peso de espigas totais (PET, em kg), Peso de espigas comerciais (PEC, em kg) e sólidos solúveis totais (SST, em ${ }^{\circ}$ Brix). A linhagem L4 foi o testador que mais proporcionou efeito de heterose. As maiores estimativas de CGC para PET e PEC foram obtidas por L4. As linhagens Balu-114 e UEM-25 foram selecionados com base nos efeitos de $\widehat{g}_{i}$ para as características estudadas e deverão ser utilizados na formação de populações base para a extração de linhagens superiores. O cruzamento BALU-182 $x$ Tropical apresentou o maior valor de $\hat{S}_{i j}$ para PET, enquanto o cruzamento BALU-94x Mista obteve o melhor valor para PEC.

Palavras-chave: análise dialélica, capacidades geral e especifica de combinação, topcross, milho doce, testador

\section{INTRODUCTION}

Sweet corn is classified as a widely consumed vegetable, with a harvest between 20 and 25 days after pollination and high post-harvest decay. The ears can be used for fresh consumption in the form of sweet corn or by canning industries, as canned, frozen, or dried corn and in the form of baby or young corn (OLIVEIRA JUNIOR et al., 2006). The sugar content, flavor, pericarp texture and thickness, duration of the harvest period and post-harvest durability of grain sweetness are some of the traits that make sweet corn more attractive for fresh consumption than field corn (BARBIERI et al., 2005).

The particularities of the most commonly used maize types allow a separation in two groups: "sweet", which contains the sugary gene and "supersweet", which carries the genes brittle (bt), shrunken (sh) or sugary enhancer (se). Corns carrying the $s h$ allele have higher sucrose contents, the sugar with highest sweetening power, aside from 
the advantage of a longer harvest period and postharvest durability (TRACY, 2001).

As a major field corn producer, Brazil has a high potential for sweet corn production. The greatest challenge is the development of sweet corn cultivars adapted to the regional conditions and that meet the requirements imposed by the processing industry. Compared to field corn, the number of sweet corn varieties available in germplasm banks is small. There are only about 300 open-pollinated sweet corn varieties in the world (TEIXEIRA et al., 2013). Brazil has only 58 registered sweet corn cultivars, few of which are available to farmers.

The narrow genetic basis of sweet corn may, in the near future, limit the advances in breeding programs and the development of new cultivars. Considering it, breeding programs seek methods that can be applied in sweet corn breeding. One of the most commonly used methods is the introduction of a gene that confers the trait sweet, known to be monogenic and recessive, of a random genetic source in a commercially used genotype with a normal endosperm, by successive backcrosses until the recovery of the desired genotype, maintaining the expression of the sweet gene (TRACY, 2001; BORDALLO et al., 2005).

Diallel analysis is one of the best methods of generating genetic information in breeding programs. This mating system allows the estimation of the general combining ability (GCA) and specific combining ability (SCA), which are associated with additive and non-additive gene effects, respectively (GRIFFING, 1956).The topcross method, among the possible evaluation methods of progenies, allowed the evaluation of the combining ability of a large number of lines, at different inbreeding levels, with a common tester. Thus, this method allowed the selection of the best lines, increasing the efficiency and making the development of hybrids more practical (MIRANDA FILHO \& VIÉGAS, 1987).

Maximization of heterotic effects should be considered in any corn breeding program, since parent grouping according to the heterotic pattern is useful in the definition of promising crosses. However, which parents would be indicated as contrasting patterns for sweet corn is still undefined. In Brazil, there are no reports of the use of the topcross technique for sweet corn lines.

The purpose of this study was to evaluate the performance of testers and tropical corn lines converted to supersweet by the introgression of the $s h$ gene with regard to the general and specific combining ability, with a view to selecting superior lines for hybrid development in sweet corn breeding.

\section{MATERIALS AND METHODS}

The study was divided in two stages: in the first, 48 field maize lines were selected for the introduction of the recessive supersweet $s h$ gene by backcrossing. The donor of gene $s h$ was the single-cross hybrid Tropical Plus. Backcrossing was continued until the recovery of $93.75 \%$ of the genes from the field maize lines. Thereafter, the lines were used as female parents in crosses with three testers: a) open-pollinated mixed variety (broad genetic base tester); b) supersweet line L4 (narrow genetic base tester); c) supersweet commercial single-cross hybrid Tropical Plus (narrow genetic base tester).

The second step consisted in the evaluation of topcross hybrids and lines per se. Three experiments were conducted to evaluate topcrosses derived from the cross of lines with each tester, and one to evaluate the per se performance of the lines. The four trials were carried out in the summer growing season of 2015/16 at two locations: on the Experimental Farm of Iguatemi $\left(23^{\circ} 25^{\prime} \mathrm{S}, 51^{\circ} 57^{\prime} \mathrm{O}, 550 \mathrm{~m}\right.$ asl), in Maringá, Paraná, and at Sementes Balu farm $\left(23^{\circ} 19^{\prime} \mathrm{S}\right.$; 5133'; 725m asl), in Sabáudia, Paraná. The trial was arranged in a complete block design with randomized treatments, with two replications. The plot consisted of one 5-m row, with rows spaced $0.70 \mathrm{~m}$ and plants $0.2 \mathrm{~m}$ apart, totaling 71,000 plants $\mathrm{ha}^{1}$.

The milky grain stage (R3) was defined as standard for the harvest of sweet corn, with a grain moisture content between 70 and $80 \%$. The following traits were evaluated: total ear weight (TEW, in $\mathrm{kg}$ ), i.e., the mean of the total weight of husked ears per treatment; commercial ear weight (CEW, in $\mathrm{kg}$ ), i.e.; the mean weight per treatment of the ears considered commercial (length $>15 \mathrm{~cm}$, diameter $>3 \mathrm{~cm}$, free of insect and disease damage); total soluble solids (TSS, in ${ }^{\circ}$ Brix).

A partial diallel analysis was performed by the model proposed by GRIFFING (1956), adapted for partial diallel crosses by Geraldi and Miranda Filho (1988), based on the treatment means of each trial. The variance components and genetic and phenotypic parameters were estimated, e.g., estimates of genetic variance $\left(\hat{\sigma}_{g}^{2}\right)$, phenotypic variance $\left(\hat{\sigma}_{f}^{2}\right)$ heritability $\left(\mathrm{h}^{2}\right)$, coetticient of genetic variation $\left(\widehat{\mathrm{CV}}_{\mathrm{g}}\right)$, and the ratio $\widehat{\mathrm{CV}}_{\mathrm{g}} \widehat{\mathrm{CV}}_{\mathrm{e}}$ of the per se lines and topcross hybrids. For the statistical and genetic analysis, software Genes was used (CRUZ, 2013).

\section{RESULTS AND DISCUSSION}

The coefficients of variation and the genetic parameters were illustrated at table1. The $\mathrm{CV}_{\mathrm{g}}$ indicates 
the proportional selection gain in relation to the mean, and a ratio of $\widehat{\mathrm{CV}}_{\mathrm{g}} \widehat{\mathrm{CV}}_{\mathrm{e}}<1$ indicates a favorable situation for selection (RODRIGUES et al., 2009).

In this study, the values of this ratio were highest in the combined analysis, i.e., 1.17, 1.02 and 0.44 for the topcrosses involving the testers L4, Tropical and Mixed variety, respectively, indicating the possibility of selection for the traits evaluated at both locations for each tester. In addition, this result showed that a major part of the variation was due to genetic variance, favoring genetic gains in relation to the original mean.

The genetic parameters indicated tester Tropical as the most efficient for TEW compared with the other two testers, since the indices of the topcrosses of the lines with this tester were good $\left(h^{2}\right.$ of 80.97 and $\mathrm{CV}_{\mathrm{g}} / \mathrm{CV}_{\mathrm{e}}$ 1.08). However, despite the apparent superiority of tester Tropical, the Mixed variety was more efficient in discriminating lines with regard to TSS; and although, the topcross means involving Tropical were higher for both TEW and $\mathrm{CEW}$, the Mixed variety proved to be the best tester for the differentiation of lines for commercial ear yield. The low $\mathrm{CV}_{\mathrm{g}}$ and heritability values (Table 1) for the per se performance of the lines indicated that genetic gains with selection may be hampered. These values suggested a separate analysis of these lines in

Table 1 - Estimates of genetic and phenotypic parameters for total ear weight (TEW), commercial ear weight (CEW) and total soluble solids (TSS) of hybrids. Growing season 2015/2016 - Sabáudia (SAB) and Maringá-PR (MGA).

\begin{tabular}{|c|c|c|c|c|c|c|}
\hline \multirow[t]{2}{*}{ Estimators } & \multicolumn{2}{|c|}{------------TEW (kg)-------- } & \multicolumn{2}{|c|}{---------CEW (kg)--------- } & \multicolumn{2}{|c|}{ 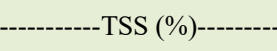 } \\
\hline & SAB & MGA & SAB & MGA & SAB & MGA \\
\hline \multicolumn{7}{|c|}{ 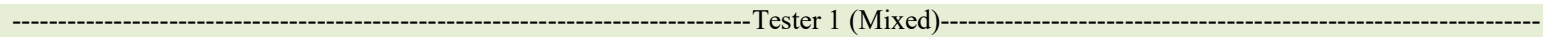 } \\
\hline$\hat{\sigma}_{g}^{2}$ & 0.20 & 0.22 & 0.38 & 0.26 & - & - \\
\hline$\hat{\sigma}_{f}^{2}$ & 0.43 & 0.30 & 0.68 & 0.37 & 0.45 & 0.62 \\
\hline$\widehat{h}^{2}$ & 45.12 & 71.257 & 56.26 & 69.58 & - & - \\
\hline$C V_{g}$ & 7.80 & 11.15 & 11.80 & 12.60 & - & - \\
\hline$C V_{g} / C V_{e}$ & 0.64 & 1.11 & 0.80 & 1.07 & - & - \\
\hline \multicolumn{7}{|c|}{ - } \\
\hline$\hat{\sigma}_{g}^{2}$ & 0.95 & 0.20 & 1.37 & 0.18 & 0.45 & - \\
\hline$\hat{\sigma}_{f}^{2}$ & 1.05 & 0.31 & 1.49 & 0.33 & 0.63 & 0.32 \\
\hline$\widehat{h}^{2}$ & 90.79 & 62.34 & 91.65 & 24.983 & 71.33 & - \\
\hline$C V_{g}$ & 15.05 & 10.06 & 19.837 & 10.03 & 4.23 & - \\
\hline$C V_{g} / C V_{e}$ & 2.22 & 0.91 & 2.34 & 0.79 & 1.12 & - \\
\hline \multicolumn{7}{|c|}{ 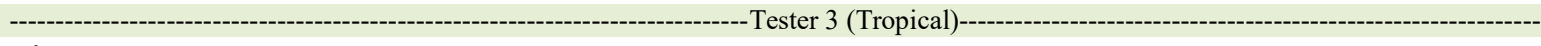 } \\
\hline$\hat{\sigma}_{g}^{2}$ & 0.38 & 0.14 & 0.56 & 0.17 & 0.35 & - \\
\hline$\hat{\sigma}_{f}^{2}$ & 0.52 & 0.22 & 0.75 & 0.26 & 0.64 & 0.56 \\
\hline$\widehat{h}^{2}$ & 73.54 & 64.62 & 75.06 & 63.72 & 55.29 & - \\
\hline$C V_{g}$ & 10.86 & 8.66 & 14.20 & 9.55 & 3.74 & - \\
\hline$C V_{g} / C V_{e}$ & 1.18 & 0.96 & 1.23 & 0.94 & 0.79 & - \\
\hline \multicolumn{7}{|c|}{ - } \\
\hline$\hat{\sigma}_{g}^{2}$ & 0.38 & 0.27 & 0.46 & 0.43 & 2.17 & 2.48 \\
\hline$\hat{\sigma}_{f}^{2}$ & 0.40 & 0.28 & 0.47 & 0.43 & 4.82 & 3.32 \\
\hline$\widehat{h}^{2}$ & 96.76 & 98.00 & 97.98 & 99.67 & 45.13 & 74.87 \\
\hline$C V_{g}$ & 20.75 & 34.045 & 37.14 & 207.59 & 8.93 & 10.22 \\
\hline$C V_{g} / C V_{e}$ & 3.86 & 4.95 & 4.92 & 12.32 & 0.64 & 1.22 \\
\hline
\end{tabular}


each environment, to ensure more consistent indices for the evaluated traits.

Results of the combined analysis of variance were statistically significant $(p<0.05)$ for the interaction topcrosses and environments. This allowed the conclusion that the performances differed between the two environments, indicating that in the mean, some genotypes had a differentiated relative performance due to environmental variations, which can be attributed to genetic differences between the respective lines of hybrid topcrosses, requiring an interpretation based on the treatment means in each tested environment.

The summary of the combined diallel analysis for the response variables TEW, CEW and TSS is shown in table 2. Results of the mean squares of the combined diallel analysis showed that the effects of the general combining ability of the topcrosses (GCAI), lines (GCAII) and also for the specific combining ability (SCA) were highly significant $(p<0.05)$ for all evaluated traits.

Significant mean square values for GCA indicated the presence of at least one genotype among the testers (group I) and another among the lines (group II) that differs from the others in the concentration of favorable alleles for the trait; independently, of the dominance type of these alleles (VENCOVSKY \& BARRIGA, 1992). Thus, results obtained in this diallel analysis indicated the presence of additive and nonadditive effects on the genotypic variance of the traits; although, the values of the quadratic components showed that the additive effects were more important than the non-additive effects on these traits.
Results for the interaction of GCAI and GCAII with environments (Table 2) showed a variable performance of lines and testers regarding their additive effects according to each environment. Similarly, the SCA - environment interaction indicated that it is important to define the best crosses in terms of the individual combining ability in each location.

The GCA estimates for the testers (GCAI) and lines (GCAII) are listed in tables 3 and 4 . The highest CA estimates for TEW and CEW were obtained by the narrow genetic base tester L4. These results demonstrated that tester L4 has the highest frequency of favorable alleles to raise the trait means, and the tester of broad genetic base Mixed variety has the lowest. Moreover, the high $\widehat{g}_{\iota}$ effects reflect the high degree of homozygosity and the narrow genetic base of line L4, aside from a good GCA with the lines converted to the trait sweet.

An optimal tester maximizes line performance and efficiently discriminates the tested lines. Although, an efficient tester can be defined as one that can generate different hybrids with itself, without strongly influencing the average performance of these hybrids. Therefore, the best tester would be a homozygous recessive line or a population with low allele frequency for the most important loci. This type of tester would be most adequate for the assessment of lines in the initial stages of selfing, from topcross mating systems (MIRANDA FILHO \& VIÉGAS, 1987).

General combining values for the Mixed variety were negative for the three variables, which may qualify this tester as an excellent option for selection of lines with good GCA, since their negative

Table 2 - Combined partial diallel analysis for total ear weight (TEW), commercial ear weight (CEW) and total soluble solids (TSS) of topcross hybrids. Growing season 2015/2016 - Sabáudia and Maringá-PR.

\begin{tabular}{|c|c|c|c|c|}
\hline \multirow[t]{2}{*}{ Sources of variation } & \multirow[t]{2}{*}{$\mathrm{DF}$} & \multicolumn{3}{|c|}{---Mean squares-------------------------------' } \\
\hline & & TEW (kg) & CEW (kg) & TSS $(\%)$ \\
\hline Topcrosses & 143 & $1.3797^{* *}$ & $1.7383^{* *}$ & $1.3886^{* *}$ \\
\hline GCA(testers) & 2 & $11.7858^{* *}$ & $12.0320^{* *}$ & $11.6452^{* *}$ \\
\hline GCA(lines) & 47 & $1.5090^{* *}$ & $2.4939^{* *}$ & $2.0175^{* *}$ \\
\hline SCA & 94 & $1.0936^{* *}$ & $1.1415^{* *}$ & $0.8559^{* *}$ \\
\hline Environments & 1 & $358.0137^{* *}$ & $240.5937^{* *}$ & $414.1225^{* *}$ \\
\hline Topcrosses $\times$ environments & 143 & $0.6199^{* *}$ & $0.9351^{* *}$ & $0.8880^{* *}$ \\
\hline GCA (testers) $\times$ environments & 2 & $5.5124^{* *}$ & $4.8069^{* *}$ & $0.1590^{*}$ \\
\hline GCA (lines) $\times$ environments & 47 & $0.5659^{* *}$ & $1.4158^{* *}$ & $1.3020^{* *}$ \\
\hline SCA $\times$ environments & 94 & $0.5428^{* *}$ & $0.6123^{* *}$ & $0.6965^{*}$ \\
\hline Combined error & 288 & 0.25250 & 0.32150 & 0.71100 \\
\hline
\end{tabular}

${ }^{*},{ }^{* *}$, significant at 5 and $1 \%$ by the $\mathrm{F}$ test, respectively. ${ }^{\mathrm{N}}$ Nonsignificantby the $\mathrm{F}$ test. 
values would facilitate the expression of good GCA of the evaluated lines. However, tester L4 proved efficient for the selection of lines to achieve genetic gains for TEW and CEW, since the GCA estimates for these traits were positive. This observation is justified by the fact that, when using an inbreeding line as tester, the main objective was to select lines for SCA, especially when the tester has relevant GCA estimates.

Tropical tester obtained negative or irrelevant estimates for TEW and CEW (Table 3), which results in an efficient discrimination of genotypes for these traits. The negative values of tester Tropical may be a consequence of its genetic correlation with the lines, for being used as donor of the gene supersweet. Therefore, the topcrosses involving these genotypes could be interpreted as intrapopulational crosses (HALLAUER \& MIRANDA FILHO, 2010).

The results for the GCA effects of lines (GCAII) are shown in table 4. Generally, a line has a higher or lower $\hat{g}_{i}$ effect than the others when the difference between the values is greater than twice the value of the calculated standard deviation. If the positive of $\hat{g}_{i}$ estimates meet this requirement, the lines under study are expected to induce an improvement in the topcross hybrids (WERLEET al., 2014). According to CRUZ and REGAZZI (2001), high positive or negative $\hat{g}_{i}$ values, respectively, showed that the parent in question is superior or inferior to the other parents of diallel, in terms of average progeny performance.

Considering the results for the GCAII estimates for trait TEW, seven lines performed better in Sabáudia and six in Maringá, with particular emphasis for line UEM-23, with highest $\hat{g}_{i}$ effects at both locations. Eight lines were considered superior for $\mathrm{CEW}$; however, there was a consistency between these lines as the evaluation sites. For TSS, nine lines had higher GCA estimates; although, none of them in both environments. Therefore, it is possible to state that the absence of a line with a higher $\hat{g}_{i}$ effect at both locations, for CEW and TSS, is related to a significant GCAII - environment interaction (Table 3 ), requiring selection of the best lines within each environment for the formation of topcross hybrids.

Considering the traits TEW and CEW, lineUEM-23 had a particularly good performance, with constant positive and significant estimates at both locations. For the same traits, there were two groups of lines that only had great values either in Sabáudia (Balu-28, Balu-29, Balu-30, UEM-9, UEM11, UEM-23, and UEM-25) or in Maringá (Balu-18, Balu-44, Balu-138, and UEM-23).

The SCA reflects the specificity between the parents involved in crosses, being explained by the effect of complementation between the alleles derived from each parent (dominant gene action) and the effect of interactions between the alleles of different loci involved in the trait transmission (epistatic gene action). High $\hat{S}_{i j}$ values, regardless of the signal, indicated that the SCA performance were different than the expected based on the GCA of the parents. Although, for selecting the best crosses based on the SCA effects, at least one parent with high GCA should be present at the cross (CRUZ et al., 2012). Furthermore, SCA is also related with the genetic distance between the parents and demonstrated the importance of non additive interactions to complement the performance of the hybrid combination.

Considering SCA results, the cross Balu182 x Tropical had positive effects for TEW in Sabáudia and CEW in Sabáudia and Maringá. For the same trait, the crosses Balu 19 x Tropical, Balu $25 \mathrm{x}$ Tropical, Balu 114 x Tropical, Balu 52 x Mista, Balu $94 \times$ Mista, and UEM $19 \times$ line L4 also had a good specific performance for both traits. Besides the SCA

Table 3 - General combining ability estimates $\left(\hat{g}_{\mathrm{i}}\right)$ of the testers for total ear weight (TEW), commercial ear weight (CEW) and total soluble solids (TSS) of topcross hybrids. Growing season 2015/2016 - Sabáudia (SAB) and Maringá-PR (MGA).

\begin{tabular}{|c|c|c|c|c|c|c|}
\hline & \multicolumn{2}{|c|}{---------------TEW (kg)------------ } & \multicolumn{2}{|c|}{----------------CEW (kg)------------ } & \multicolumn{2}{|c|}{------------TSS (\%)-------- } \\
\hline & $\mathrm{SAB}$ & MGA & SAB & MGA & SAB & MGA \\
\hline Mixed variety & -0.224 & -0.158 & 6.15 & -0.178 & -0.29 & -0.28 \\
\hline L4 & 0.463 & 0.096 & 0.449 & 0.106 & 0.17 & 0.11 \\
\hline Tropical Plus & 47 & 0.062 & -0.208 & 0.072 & 0.12 & 0.17 \\
\hline $\operatorname{SD}\left(\hat{g}_{\mathrm{i}}\right)$ & 0.047 & 0.036 & 0.053 & 0.041 & 0.06 & 0.08 \\
\hline $\mathrm{SD}\left(\hat{g}_{\mathrm{i}}-\hat{g}_{\mathrm{i}}^{\prime}\right)$ & 0.081 & 0.063 & 0.092 & 0.070 & 0.10 & 0.14 \\
\hline
\end{tabular}


Table 4 - Estimates of general combining ability $\left(\widehat{g}_{\mathrm{i}}\right)$ of the lines for total ear weight (TEW), commercial ear weight (CEW) and total soluble solids (TSS). Growing season 2015/2016 - Sabáudia (SAB) and Maringá-PR (MGA).

\begin{tabular}{|c|c|c|c|c|c|c|}
\hline \multirow[t]{2}{*}{$\hat{g}_{\mathrm{i}}$ effect } & \multicolumn{2}{|c|}{----------------TEW (kg)------------- } & \multicolumn{2}{|c|}{------------------CEW (kg)------------ } & \multicolumn{2}{|c|}{------'TSS (\%)-----. } \\
\hline & SAB & MGA & $\mathrm{SAB}$ & MGA & SAB & MGA \\
\hline Balu-3 & 122.5 & -0.987 & 0 & 37.895 & 1.07 & 0.27 \\
\hline Balu-7 & 0.042 & 0.220 & 0.079 & 0.267 & -0.13 & 0.17 \\
\hline Balu-8 & -0.086 & 0.204 & -0.024 & 0.284 & -0.23 & 0.51 \\
\hline Balu-9 & 0.029 & 0.122 & 0.103 & 0.178 & 0.37 & 0.01 \\
\hline Balu-18 & 0.034 & 0.390 & 0.148 & 0.427 & 0.17 & -0.26 \\
\hline Balu-20 & 24.983 & 0.253 & -0.635 & 0.252 & -0.23 & -0.59 \\
\hline Balu-21 & -0.654 & 51.612 & 9.4 & -0.085 & -0.27 & -0.09 \\
\hline Balu-22 & 24.983 & -0.180 & -0.323 & -0.085 & -0.43 & 0.04 \\
\hline Balu-28 & 0.876 & 0.036 & 1.148 & 0.069 & 1.20 & 0.07 \\
\hline Balu-29 & 0.899 & 0.088 & 1.064 & 0.140 & 0.17 & 0.04 \\
\hline Balu-30 & 0.567 & 0.026 & 0.731 & 0.117 & -0.13 & 1.21 \\
\hline Balu-40 & -0.079 & -0.069 & -0.278 & 0.124 & 0.10 & 0.84 \\
\hline Balu-44 & 0.110 & 0.416 & 0.084 & 0.418 & -0.37 & 0.11 \\
\hline Balu-48 & -0.553 & 0.164 & -0.508 & 0.172 & -0.87 & -0.06 \\
\hline Balu-52 & 0.147 & -0.058 & 47 & -0.112 & 0.50 & -0.03 \\
\hline Balu-55 & -0.103 & 0.147 & 0.090 & 0.164 & 0.54 & 0.14 \\
\hline Balu-56 & 0.220 & -0.135 & 0.225 & -0.199 & 0.20 & 0.24 \\
\hline Balu-58 & -0.043 & -0.142 & 0.076 & -0.070 & -0.17 & -0.03 \\
\hline Balu-72 & -0.011 & 0.265 & 0.283 & 0.288 & -0.13 & -0.03 \\
\hline Balu-79 & -0.072 & 0.381 & -0.103 & 0.303 & 24.983 & -0.26 \\
\hline Balu-80 & 51.612 & 0.237 & -0.050 & 0.290 & -1.10 & -0.76 \\
\hline Balu-83 & -0.113 & 0.069 & 0.097 & 0.125 & -0.40 & 0.31 \\
\hline Balu-89 & -0.605 & -0.359 & 9.4 & -0.248 & 0.04 & -0.33 \\
\hline Balu-90 & -0.854 & -0.192 & -0.652 & 18.25 & 0.07 & -0.69 \\
\hline Balu-94 & -0.086 & -0.179 & 0.096 & -0.279 & 0.14 & -0.09 \\
\hline Balu-95 & -0.147 & -0.486 & -0.211 & 6.15 & 0.04 & 0.77 \\
\hline Balu-111 & -0.022 & -0.037 & 0.102 & 0.007 & 0.67 & 0.34 \\
\hline Balu-114 & 0.184 & -0.066 & 0.335 & -0.010 & 0.77 & -0.39 \\
\hline Balu-115 & 0.158 & -0.166 & 0.182 & -0.156 & -0.13 & 0.27 \\
\hline Balu-116 & -0.087 & -0.153 & 19.5 & -0.134 & -0.33 & 0.07 \\
\hline Balu-138 & 0.373 & 0.676 & 0.548 & 0.765 & 0.47 & 0.61 \\
\hline Balu-143 & 0.209 & -0.487 & 0.446 & 51.612 & -0.17 & -0.26 \\
\hline Balu-148 & -0.011 & -0.434 & 0.133 & -0.388 & -1.17 & -0.16 \\
\hline Balu-169 & -0.081 & 0.323 & 0.176 & 0.379 & -0.17 & -1.59 \\
\hline Balu-181 & 0.051 & -0.104 & 0.437 & 76 & 0.24 & 0.24 \\
\hline Balu-182 & -1.127 & -0.488 & -1.030 & -0.473 & -0.63 & 0 \\
\hline Balu-183 & -0.168 & -0.090 & 0.014 & -0.200 & -0.80 & 0.41 \\
\hline Balu-185 & -0.961 & -0.584 & -0.790 & -0.637 & -0.30 & 0.31 \\
\hline UEM-3 & -122.291 & -0.497 & -0.029 & -0.537 & 0.07 & 0.87 \\
\hline UEM-6 & -0.269 & -0.060 & 79 & 12.5 & 0.67 & 0.21 \\
\hline UEM-9 & 0.731 & 0.128 & 0.806 & -0.049 & 0.17 & -0.99 \\
\hline UEM-10 & 0.434 & 0.407 & 0.457 & 0.378 & 0.24 & 0.21 \\
\hline UEM-11 & 0.720 & 0.282 & 0.729 & 0.228 & 0.50 & 0.11 \\
\hline UEM-16 & 0.306 & 0.010 & 0.157 & 0.014 & 0.54 & 0.37 \\
\hline UEM-19 & 0.380 & 0.244 & 0.490 & 0.175 & -0.13 & -0.73 \\
\hline UEM-22 & 0.114 & 0.334 & 76 & 0.341 & -0.17 & -0.59 \\
\hline UEM-23 & 0.604 & 0.598 & 0.707 & 0.584 & 0.57 & -0.13 \\
\hline UEM-25 & 1.094 & 0.004 & 1.028 & -0.109 & 0.37 & 0.21 \\
\hline $\operatorname{SD}\left(\hat{g}_{\mathrm{i}}\right)$ & 0.227 & 0.176 & 0.257 & 0.197 & 0.292 & 0.383 \\
\hline $\operatorname{SD}\left(\hat{g}_{\mathrm{i}}-\hat{g}_{\mathrm{i}}^{\prime}\right)$ & 0.324 & 0.252 & 0.368 & 0.281 & 0.417 & 0.548 \\
\hline $2 \mathrm{x} \mathrm{SD}\left(\hat{g}_{\mathrm{i}}\right)$ & 0.454 & 0.352 & 0.514 & 0.394 & 0.584 & 0.766 \\
\hline
\end{tabular}


significance effect for TSS, the $\hat{S}_{i j}$ values obtained in this study were not promising for enhancing this trait.

The cross Balu-182 $\times$ Tropical showed the highest $\hat{S}_{i j}$ value for TEW (0.711) and CEW (1.270) in Sabáudia. Likewise, the crossBalu-94 x Mixed variety had the highest value (0.750) for CEW in Maringá. Thus, these lines can be used as testers of lines derived from the respective testers. Therefore, the development of new lines derived from each one of these testers that can provide high GCA estimates is recommended.

In diallel analyses, only SCA estimates originated from crosses involving at least one parent with high GCA should be considered. In this way, analyzing GCA estimates simultaneously, only two inbred lines stand out among the highest values in both tables of estimates, Balu-114 and UEM-25. No cross had relevant $\hat{S}_{i j}$ estimates for both testers. This finding suggested that the testers have different genetic bases, with the ability to generate high heterosis in crosses with different groups of lines. This result allowed the conclusion that the testers used are originated from distinct heterotic groups.

\section{CONCLUSION}

Line L4 was the tester that provided highest heterotic effects in crosses with the lines. Highest GCA estimates for TEW and CEW were obtained by L4. The lines Balu-114 and UEM-25 were selected based on the $\hat{g}_{i}$ effects for the traits studied and should be included in the formation of base populations for the breeding of superior lines. Cross BALU-182 x Tropical had the highest $\hat{S}_{i j}$ value for TEW and cross BALU-94 x Mista for CEW.

\section{ACKNOWLEDGEMENTS}

The authors thank to the e Conselho Nacional de Desenvolvimento Científico e Tecnológico (CNPq) and the Coordenação de Aperfeiçoamento de Pessoal de Nível Superior (CAPES) for the financial support.

\section{DECLARATION OF CONFLICT OF} INTERESTS

The authors declare no conflict of interest. The founding sponsors had no role in the design of the study; in the collection, analyses, or interpretation of data; in the writing of the manuscript, and in the decision to publish the results.

\section{AUTHORS' CONTRIBUTIONS}

All authors contributed equally for the conception and writing of the manuscript. All authors critically revised the manuscript and approved of the final version.

\section{REFERENCES}

BARBIERI, V. H. B. et al. Produtividade e rendimento industrial de híbridos de milho doce em função de espaçamentos e populações de plantas. Horticultura Brasileira, Brasília, v.23, n.3, p.826-830, 2005. Available from: <http://www.scielo.br/pdf/\%0D/hb/v23n3/ a27v23n3.pdf $>$. Accessed: Oct. 21, 2018. doi: 10.1590/S010205362005000300027 .

BORDALlO, P. N.; et al. Análise dialélica de genótipos de milho doce e comum para caracteres agronômicos e proteína total. Horticultura Brasileira, Brasília, v.23, n.1, p.123-127, 2005. Available from: <http://www.scielo.br/pdf/hb/v23n1/ a26v23n1.pdf $>$. Accessed: Oct. 12, 2018. doi: 10.1590/S010205362005000100026

CRUZ, C.D. Genes - a software package for analysis in experimental statistics and quantitative genetics. Acta Scientiarum, Maringá, v.35, n.3, p.271-276, 2013. Available from: <http://www.scielo. br/pdf/asagr/v35n3/v35n3a01.pdf $>$. Accessed: Aug. 24, 2018. doi: 10.4025/actasciagron.v35i3.21251.

CRUZ, C. D. and REGAZZI, A. J. Modelos biométricos aplicados ao melhoramento genético. Viçosa: Editora UFV, 2001. 390 p.

CRUZ, C. D.; REGAZZI, A. J.; CARNEIRO, P. C. S. Modelos biométricos aplicados ao melhoramento genético. Viçosa: UFV, 2012. 514p.

GRIFFING, B. Concept of general and specific combining ability in relation to diallel crossing systems. Australian Journal of Biological Sciences, v.9, n.1, p.463-493, 1956. Available from: $<$ http://www.publish.csiro.au/bi/pdf/BI9560463>. Accessed: Sep. 05, 2018.

HALLAUER, A. R.; MIRANDA FILHO, J. B. Quantitative genetics in maize breeding. New York: Springer, 2010. 664p.

MIRANDA FILHO, J. B.; VIÉGAS, G. P. Milho híbrido. In: Paterniani, E.; Viégas, G. P. (Ed.). Melhoramento e produção do milho. 2. ed. Campinas:Fundação Cargill, 1987, Cap.7, p. $275-340$

OLIVEIRA JUNIOR, L. F. G.; et al. Seleção de genótipos de milho mais promissores para o consumo in natura. Ciência e Tecnologia de Alimentos, Campinas, v.26, n.1, p.159165, 2006. Available from: <http://www.scielo.br/pdf/cta/ v26n1/28865.pdf>. Accessed: Oct. 15, 2018. doi: 10.1590/ S0101-20612006000100026.

RODRIGUES, F.; et al. Capacidade de combinação entre linhagens de milho visando à produção de milho verde. Bragantia, Campinas, v.68, n.1, p.75-84, 2009. Available from: <http://www.scielo.br/ pdf/brag/v68n1/a09v68n1.pdf>. Accessed: Aug. 23, 2018. doi: 10.1590/S0006-87052009000100009.

TEIXEIRA, F. F; et al. Melhoramento do milho doce. Sete Lagoas: Embrapa Milho e Sorgo, 2013. 32p. (Embrapa Milho e Sorgo. Documentos, 154).

TRACY, W. F. Sweet corn. In: Hallauer, A.R. Specialty corn. Boca Raton, 2001. p.155-198.

VENCOVSKY, R.; BARRIGA, P. Genética biométrica no fitomelhoramento. Ribeirão Preto: [S.ed.], 1992. 496p.

Ciência Rural, v.50, n.3, 2020. 